\title{
Comparing the influence of net and gross anthropogenic land-use and land-cover changes on the carbon cycle in the MPI-ESM
}

\author{
S. Wilkenskjeld, S. Kloster, J. Pongratz, T. Raddatz, and C. H. Reick \\ Land in the Earth System, Max Planck Institute for Meteorology, Hamburg, Germany \\ Correspondence to: S. Wilkenskjeld (stiig.wilkenskjeld@mpimet.mpg.de)
}

Received: 24 January 2014 - Published in Biogeosciences Discuss.: 4 April 2014

Revised: 4 July 2014 - Accepted: 4 August 2014 - Published: 11 September 2014

\begin{abstract}
Global vegetation models traditionally treat anthropogenic land-use and land-cover changes (LULCCs) only as the changes in vegetation cover seen from one year to the next (net transitions). This approach ignores subgridscale processes such as shifting cultivation which do not affect the net vegetation distribution but which have an impact on the carbon budget. The differences in the carbon stocks feed back on processes like wildfires and desert formation. The simulations for the Coupled Model Intercomparison Project Phase 5 (CMIP5) all describe LULCCs using the "Land-Use Harmonization Dataset". Though this dataset describes such subgrid-scale processes (gross transitions), some of the CMIP5 models still use the traditional approach. Using JSBACH/CBALANCE - the land carbon component of the Max Planck Institute Earth System Model (MPIESM), this study demonstrates how this potentially leads to a severe underestimation of the carbon emissions from LULCCs. Using net transitions lowers the average land-use emissions from 1.44 to $0.90 \mathrm{Pg} \mathrm{Cyr}^{-1}(38 \%)$ during the historical period (1850-2005) - a total lowering by $85 \mathrm{Pg} \mathrm{C}$. The difference between the methods is smaller in the RCP scenarios (2006-2100) but in RCP2.6 and RCP8.5 still cumulates to $30-40 \mathrm{PgC}$ (on average $0.3-0.4 \mathrm{Pg} \mathrm{C} \mathrm{yr}^{-1}$ or $13-25 \%$ ). In RCP4.5 essentially no difference between the methods is found. Results from models using net transitions are furthermore found to be sensitive to model resolution.
\end{abstract}

\section{Introduction}

Since prehistoric times humans have been changing the surface of the Earth to suit their purposes (Williams, 2006). These changes include conversion of natural vegetation to agricultural land (e.g. by slash burning) and wood harvest for fuel and construction usage. The anthropogenic land-use and land-cover changes (LULCCs) have increased with growing human population and its associated agricultural needs (Pongratz et al., 2008). LULCCs remove carbon from the natural vegetation and thus perturb the natural land carbon cycle. Previous studies have shown that carbon emissions from LULCCs exceeded other anthropogenic carbon sources (such as burning of fossil fuel and cement production) until far after the onset of industrialization (Houghton et al., 1983; Pongratz et al., 2009; Reick et al., 2010). Still in the 1980 s, carbon emissions from LULCCs accounted for up to $20 \%$ of the total anthropogenic carbon emissions (Denman, 2007). The published LULCC carbon emissions (Houghton et al., 2012, and references therein) exhibit a huge span. Several studies have addressed possible reasons for this span: different model type (Houghton et al., 2012; Reick et al., 2010), different LULCC data sets applied (Shevliakova et al., 2009; Jain et al., 2013), nitrogen limitation on regrowth (Jain et al., 2013) and different definitions of what is meant by LULCC emissions (Pongratz et al., 2014). This study addresses the differences arising from the inclusion or exclusion of subgrid-scale LULCCs which is the difference between net and gross LULCC algorithms.

In the framework of the 5th phase of the Coupled Model Intercomparison Project (CMIP5) a series of experiments covering the recent past and future scenarios were defined to facilitate direct comparisons between the results of different coupled models (Taylor et al., 2012) contributing to the 5th Assessment Report (AR5) of the Intergovernmental Panel on Climate Change (IPCC). Several of the Earth System Models (ESMs) participating in CMIP5 implemented LULCCs into an interactive carbon cycle. However, the implementa- 
tion details of LULCCs in the different ESMs are diverse (Brovkin et al., 2013), and so are the results with respect to the influence of LULCCs on the carbon cycle (Houghton et al., 2012, and references therein). One aspect in which the implementations differ, is whether the models implement LULCCs by a net or a gross algorithm.

Gross algorithms account for the possibility that there might be grid cells in which at some time, for example, grassland is turned into cropland while at the same time elsewhere in the same grid cell cropland is abandoned. In the net algorithms such simultaneous, bidirectional land-use changes within a grid cell are not accounted for, and the models only see the net gain or loss of agricultural area during a LULCC time step. In some parts of the world shifting cultivation clearing a piece of natural land, farming it for some years, abandoning it again while clearing another piece of natural land - is a common practice (Lanly, 1985; Ranjan and Upadhyay, 1999; Bruun et al., 2006; Lojka et al., 2011). Though shifting cultivation does not change the vegetation distribution, as is seen by global models, it releases carbon from the natural vegetation. These carbon fluxes are not accounted for when using a net algorithm. Therefore also the carbon stocks are different which may cause different behaviour of other modelled effects - e.g. wildfires. Though not addressed in this study, the two methods also leave the vegetation in different states, which affects their canopy structure, growth and biogeophysical properties such as albedo and roughness length.

Although Houghton et al. (1983) included gross conversion effects in their bookkeeping model, Hurtt et al. (2006) were the first to provide a data set which accounts for such cultivation practices by describing the anthropogenic land surface transformations within a grid cell bi-directionally in a form usable by grid-cell-based global vegetation models (GVMs). An update to this data set - the so-called Land-Use Harmonization Dataset - was presented in Hurtt et al. (2011) and used by all CMIP5 models implementing LULCCs.

The present study addresses the differences in carbon emissions arising from applying net or gross transitions using the same model, JSBACH/CBALANCE, by re-running a sub-set of the CMIP5 experiments performed with the Max Planck Institute for Meteorology Earth System Model (MPIESM) (Giorgetta et al., 2013).

Section 2 describes the model and how LULCC (both gross and net) is implemented, Sect. 3 explains the performed experiments, while the results are described in Sect. 4 and discussed in a broader context in Sect. 5 .

\section{The model}

In the present study CBALANCE, the carbon cycle and vegetation distribution component of the land vegetation model JSBACH (Raddatz et al., 2007; Brovkin et al., 2009; Reick et al., 2013) of the MPI-ESM, was used. CBALANCE can be run as a stand-alone model which is capable of reproducing exactly the results of the coupled MPI-ESM model with respect to the land carbon cycle and land vegetation cover, when it is forced by the output (net primary production, leaf area index, atmospheric and soil parameters) from the coupled model, with low computational costs.

CBALANCE was run globally in the same setup as the MPI-ESM CMIP5 LR-experiments (Giorgetta et al., 2013; Schneck et al., 2013) - i.e. on the T63 grid (resolution of $\left.\approx 1.87 \times 1.87^{\circ}\right)$. In each grid cell up to 11 plant functional types (PFTs) out of a total of 13 different PFTs (4 forest, 2 shrub, 2 grassland, 2 pasture, 2 crop and 1 glacier/other permanently inhospitable land) can be present. Furthermore, each grid cell can contain a fraction of temporarily inhospitable land (desert) (see Reick et al., 2013).

\subsection{Land-use transitions}

In JSBACH/CBALANCE the LULCC in each grid cell is described by annual conversion factors of the bidirectional transformations between any pair of the three vegetation classes: natural (which includes forest, shrublands and unmanaged grasslands, subscript: $\mathrm{N})$, pasture $(\mathrm{P})$ and crop $(\mathrm{C})$ :

$$
\left(\begin{array}{c}
c_{\mathrm{N}} \\
c_{\mathrm{C}} \\
c_{\mathrm{P}}
\end{array}\right)^{k+1}=\left(\begin{array}{ccc}
\alpha_{\mathrm{N} \rightarrow \mathrm{N}} & \alpha_{\mathrm{C} \rightarrow \mathrm{N}} & \alpha_{\mathrm{P} \rightarrow \mathrm{N}} \\
\alpha_{\mathrm{N} \rightarrow \mathrm{C}} & \alpha_{\mathrm{C} \rightarrow \mathrm{C}} & \alpha_{\mathrm{P} \rightarrow \mathrm{C}} \\
\alpha_{\mathrm{N} \rightarrow \mathrm{P}} & \alpha_{\mathrm{C} \rightarrow \mathrm{P}} & \alpha_{\mathrm{P} \rightarrow \mathrm{P}}
\end{array}\right)\left(\begin{array}{c}
c_{\mathrm{N}} \\
c_{\mathrm{C}} \\
c_{\mathrm{P}}
\end{array}\right)^{k},
$$

where $c$ is the fraction of a grid cell vegetated with plants from the corresponding vegetation class, $k$ is the discrete time and the conversion factors $\alpha$ are the fraction of the area of a given vegetation class converted to a given other vegetation class. The six off-diagonal matrix elements are obtained from an external data set. Due to conservation of area, the diagonal elements are given by $\alpha_{i \rightarrow i}=1-\sum_{j, j \neq i} \alpha_{i \rightarrow j}$ for $i, j \in\{\mathrm{N}, \mathrm{C}, \mathrm{P}\}$. Since this formulation allows simultaneous conversions between any pair of vegetation classes, JSBACH/CBALANCE is capable of doing gross LULCC.

In general, the area converted between vegetation classes is distributed so that each PFT within the relevant vegetation classes gains or loses the same fraction of its area. However, to emulate typical cultural practices JSBACH/CBALANCE treats forest (incl. shrublands) and grasslands as two different vegetation classes. For conversion from natural vegetation to pasture, preferentially grasslands are converted, and conversely re-establishment of forest has priority when pasture is abandoned. When converting natural vegetation to crops, the land is taken from both forest and grasslands proportional to their fraction of area after conversions from natural vegetation to pasture has been applied. Details on this "pasture rule" and LULCC in JSBACH/CBALANCE in general are found in Reick et al. (2013).

In JSBACH/CBALANCE $80 \%$ of the carbon of the living plants on the converted area is released to the atmosphere immediately while the remaining $20 \%$ is transformed to litter. The litter carbon already present at the converted area 
Table 1. Performed experiments. RCP-forced experiments include runs for RCP2.6, RCP4.5 and RCP8.5. Experiments with no LULCC have their distribution of agricultural land fixed at the time where also the harvest from the natural vegetation is fixed. The hist_none experiments are restarted from the coupled piControl experiment so that hist_gross reproduces the "r1" ensemble member. "\#”: number of scenarios for this setup, “Alg”: LULCC algorithm, “Trans.”: transient, "Frc.”: forcing, "hist.”: historical.

\begin{tabular}{lcclllll}
\hline Experiment & $\#$ & Period & Alg. & Harvest & Frc & Restart from & Purpose \\
\hline hist_none & 1 & $1850-2005$ & None & $=1850$ & hist. & piControl & Ref. for hist_gross, hist_net \\
hist_harv & 1 & $1850-2005$ & None & Trans. & hist. & piControl & Alt. ref. for hist_gross, hist_net \\
hist_gross & 1 & $1850-2005$ & Gross & Trans. & hist. & piControl & LCE gross transitions, hist. period \\
hist_net & 1 & $1850-2005$ & Net & Trans. & hist. & piControl & LCE net transitions, hist. period \\
RCP_none & 3 & $2006-2100$ & None & $=1850$ & RCP & hist_none & Ref. for RCP_gross, RCP_net. \\
RCP_harv & 3 & $2006-2100$ & None & Trans. & RCP & hist_harv & Alt. ref. for RCP_gross, RCP_net \\
RCP_gross & 3 & $2006-2100$ & Gross & Trans. & RCP & hist_gross & LCE gross trans., RCP period \\
RCP_net & 3 & $2006-2100$ & Net & Trans. & RCP & hist_net & LCE net trans., RCP period \\
\hline
\end{tabular}

is assumed to stay where it is physically located and is thus reassigned to the PFT taking over the location.

\subsection{Net land-use transitions}

Net transitions are applied using the standard JSBACH/CBALANCE transition scheme, but using a reduced data set derived from the gross data set during run time. The derivation is done by applying the principle of minimum transitions: at the start of each year, the annual gross transitions are - using Eq. (1) - applied to the actual PFT distribution to obtain the PFT distribution at the start of the next year. The difference between the two PFT distributions is then used to determine the conversion factors resulting in the same PFT distribution minimizing the land conversions. In this case at most two of the non-diagonal factors $\alpha$ are non-zero. This is equivalent to the traditional approach, pre-describing a map with the vegetation distribution each year.

\subsection{Harvest of carbon from natural vegetation}

Harvest of natural vegetation is the process of humans removing part of the biomass without altering the type of vegetation - i.e. a forest is still a forest though a few trees are removed. In JSBACH/CBALANCE wood harvest is implemented as a pre-described removal of biomass in terms of carbon. All natural PFTs contribute carbon to the harvest request in the same fraction as their above-ground living carbon. A part of the harvested carbon (20\%) is released directly to the atmosphere at the time of harvest. The rest is treated as litter and is respired to the atmosphere with a time delay. Depending on the climatic conditions and vegetation a small fraction of the harvested carbon may be deposited in the soil for a very long time. If the prescribed harvest of carbon exceeds the living natural carbon stocks in a grid box, only the available carbon is harvested.

\section{Data and experiments}

The carbon fluxes presented in this study are equivalent to the "net land-use flux" as defined in Pongratz et al. (2014), but to avoid confusion about the word "net", here the fluxes are termed "land-use carbon emissions" (LCEs). The cumulated LCE is the difference between the total carbon stored on land between an experiment with LULCC and one without. This method takes into account both the direct carbon transfer to the atmosphere, indirect effects like adjustment of primary production as well as delayed emissions from soil/litter respiration. In the main experiments without LULCC wood is still harvested at a fixed rate corresponding to the prescribed rate at the starting year of the experiment. To separate the LCE from harvest and land-use changes, additional experiments with transient wood harvest and no land-use changes have been conducted. Comparing LCE from gross and net transitions requires three experiments for each scenario: one without LULCC, one with gross and one with net LULCC.

The LULCC data used (including data on wood harvest), were taken from the "Land-Use Harmonization Dataset" (Hurtt et al., 2011) also used for the MPI-ESM CMIP5 experiments. All experiments were applying the dynamic vegetation of JSBACH/CBALANCE (Brovkin et al., 2009, 2013; Reick et al., 2013) to determine the distribution of deserts and natural PFTs.

CBALANCE was forced with the daily output from the MPI-ESM CMIP5 scenarios from MPI-ESM ensemble member "r1" (Giorgetta et al., 2013) from the respective scenario, and the initial (1850) vegetation distribution and carbon pools were accordingly taken from the piControl experiment.

Four of the CMIP5 scenarios (Taylor et al., 2012) were redone: the historical (1850-2005) and the three of the RCP (2006-2100) scenarios (van Vuuren et al., 2011a) for which forcing data from the MPI-ESM were available: RCP2.6 (van Vuuren et al., 2011b), RCP4.5 (Thomson et al., 2011) and RCP8.5 (Riahi et al., 2011). In total 16 runs were performed, logically assigned to eight experiments (Table 1) differing by the time period (historical or RCP) and the LULCC type 
(i.e. no land-cover change with fixed harvest, no land-cover change with transient harvest, net LULCC or gross LULCC).

The experiments hist_gross and RCP_gross exactly reproduce the CMIP5 experiments with the coupled MPIESM; hist_net and RCP_net are equivalent, just using net transitions instead of gross; and hist_none and RCP_none serve as reference runs for LCE calculations for the respective gross/net experiments. The difference between hist_harv (RCP_harv) and hist_none (RCP_none) is used to assess the contribution of wood harvest to the LCE.

\section{Results}

\subsection{Vegetation distribution}

\subsubsection{Natural changes}

Due to the dynamic vegetation in JSBACH/CBALANCE and a changing climate, vegetation distribution is changing over time even in the experiments not applying LULCC (hist_none, RCP_none, dashed lines in Fig. 1). From 1850 to 2100 the desert area decreases by $9-12.5 \times 10^{6} \mathrm{~km}^{2}$ (depending on the RCP scenario) of which $1 / 2-2 / 3$ occur during the RCP period (2006-2100). The decrease mainly occurs in high northern latitudes and is compensated by a proportional increase in all natural vegetation classes. The decrease of desert area is largest for RCP8.5, less for RCP4.5 and least for RCP2.6.

\subsubsection{Changes from LULCC}

When applying LULCC (no matter if gross or net), the most pronounced change in vegetation cover (Figs. 1 and 2) is the conversion of forest and grassland into crop and pasture during the historical period (1850-2005). The global net effect is that in total $27.2 \times 10^{6} \mathrm{~km}^{2}$ of natural vegetation and $3.8 \times 10^{6} \mathrm{~km}^{2}$ desert is lost and $9.7 \times 10^{6} \mathrm{~km}^{2}$ crop and $21.3 \times 10^{6} \mathrm{~km}^{2}$ of pasture is gained. The areas actually converted during the period are much larger (gross: $\approx 135 \times 10^{6} \mathrm{~km}^{2}$, net: $\approx 40 \times 10^{6} \mathrm{~km}^{2}$ ), but most of these conversions cancel each other globally (both LULCC forms) and on subgrid-scale (gross LULCC only).

In the RCP4.5 scenario the natural vegetation has in year 2100 regained about $1 / 3$ of the area which was cultivated during the historical period - partly by reducing agricultural land, partly because of forest expansion in the high northern latitude desert areas (Supplement Fig. S2). RCP2.6 and RCP8.5 both show a stabilization of the global natural vegetation (about $24 \times 10^{6} \mathrm{~km}^{2}$ forest and $20 \times 10^{6} \mathrm{~km}^{2}$ grassland, Supplement Figs. S1 and S3). This global stabilization however stems from decreasing forests in the Southern Hemisphere compensated by an increase in forest area in the high northern latitudes. These two scenarios increase cultivated areas, globally balancing the decreasing desert area, which is slightly less (up to $500 \times 10^{3} \mathrm{~km}^{2}$ ) with LULCC than without.

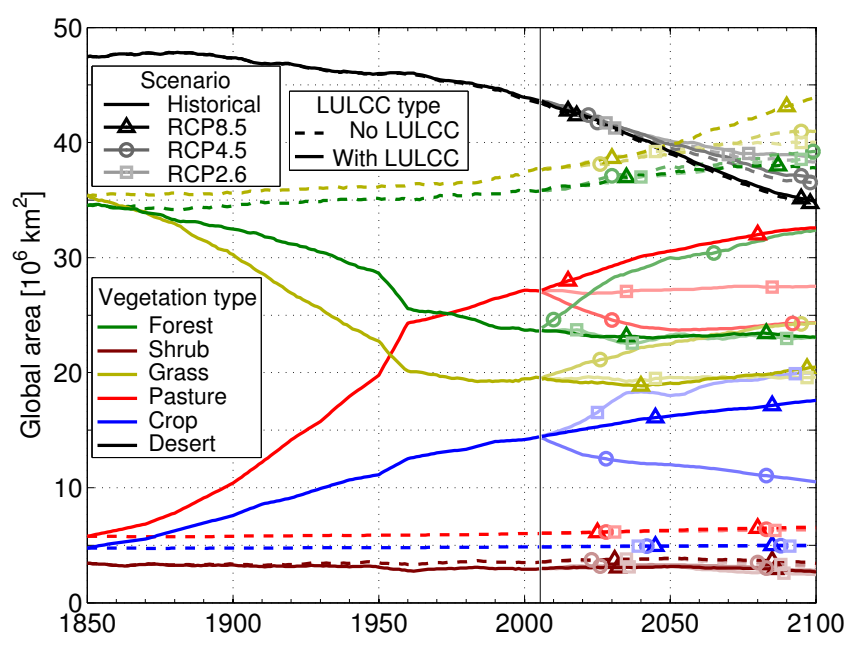

Figure 1. Evolution of the global area of different vegetation and surface types resulting from gross and no LULCC combined with dynamic vegetation. Different experiments have different line styles, different surface types have different colour and different scenarios have different brightness (same brightness for historical and RCP8.5, since they do not have any temporal overlap). Desert: area without vegetation under current climate. Glacier and bare rock area which can never have vegetation is constant about $16 \times 10^{6} \mathrm{~km}^{2}$ throughout the experiments. Minor differences between net and gross LULCC are discussed in the text.

In RCP 8.5 both crop and pasture areas are increased, while in RCP2.6 mainly cropland is increased. During the RCP period a total of $127(13) \times 10^{6}, 91(10) \times 10^{6}$ and $112(9) \times 10^{6} \mathrm{~km}^{2}$ are gross (net) converted in RCP2.6, RCP4.5 and RCP8.5, respectively (Supplement Figs. S4 and S5).

It is expected that gross and net LULCC result in the same vegetation distribution (Fig. 1). Due to complicated non-linear interactions between LULCC including the pasture rule, the dynamic vegetation, wildfires, and the way the JSBACH/CBALANCE prevents its living carbon pools from being unrealistically large, this is however not entirely fulfilled. The largest differences are that globally net LULCC results in $\approx 300 \times 10^{3} \mathrm{~km}^{2}$ extra grassland $(88 \%)$ and pasture $(12 \%)$ on the cost of forests $(76 \%)$ and desert $(24 \%)$ compared to gross LULCC. That the area of pasture can become different is a consequence of the changing desert area and the fractional formulation of the transitions. The differences in vegetation distribution between gross and net LULCC experiments are in the same direction in most regions of the world, and thus regional signals do not cancel much on the global scale. For comparison, global arable land is $\approx 100 \times 10^{6} \mathrm{~km}^{2}$.

\subsection{Land-use carbon emissions (LCEs)}

\subsubsection{LCE from net LULCC}

The historical LCE from net LULCC (Fig. 3) increases almost linearly from $0.2 \mathrm{PgCyr}^{-1}$ in 1850 to about 
Table 2. Annual average LCE $\left[\mathrm{Pg} \mathrm{C} \mathrm{yr}^{-1}\right]$ and LCE accumulated over entire experiment $[\mathrm{PgC}]$. Scenario "historical" calculated from experiments hist_gross (hist_net) and hist_ref, experiments "RCP" from RCP_gross (RCP_net) and RCP_ref. "Harvest" is calculated from the difference between hist_none (RCP_none) and hist_harv (RCP_harv). The LCE from wood harvest is included in the numbers for both "gross" and "net".

\begin{tabular}{llcccccc}
\hline Scenario & & \multicolumn{3}{c}{ Historical } & \multirow{2}{*}{ RCP2.6 } & RCP4.5 & RCP8.5 \\
\cline { 3 - 5 } & & $1990 \mathrm{~s}$ & 2005 & $1850-2005$ & & & \\
\hline Gross & (annual) & 2.05 & 2.09 & 1.44 & 1.69 & 0.12 & 2.38 \\
Net & (annual) & 1.40 & 1.59 & 0.90 & 1.26 & 0.10 & 2.06 \\
Harvest & (annual) & 0.21 & 0.21 & 0.09 & 0.22 & 0.26 & 0.32 \\
\hline Gross & (cumulated) & & & 225 & 160 & 11.9 & 226 \\
Net & (cumulated) & & & 140 & 120 & 9.5 & 196 \\
Harvest & (cumulated) & & & 13 & 21 & 25 & 31 \\
\hline
\end{tabular}

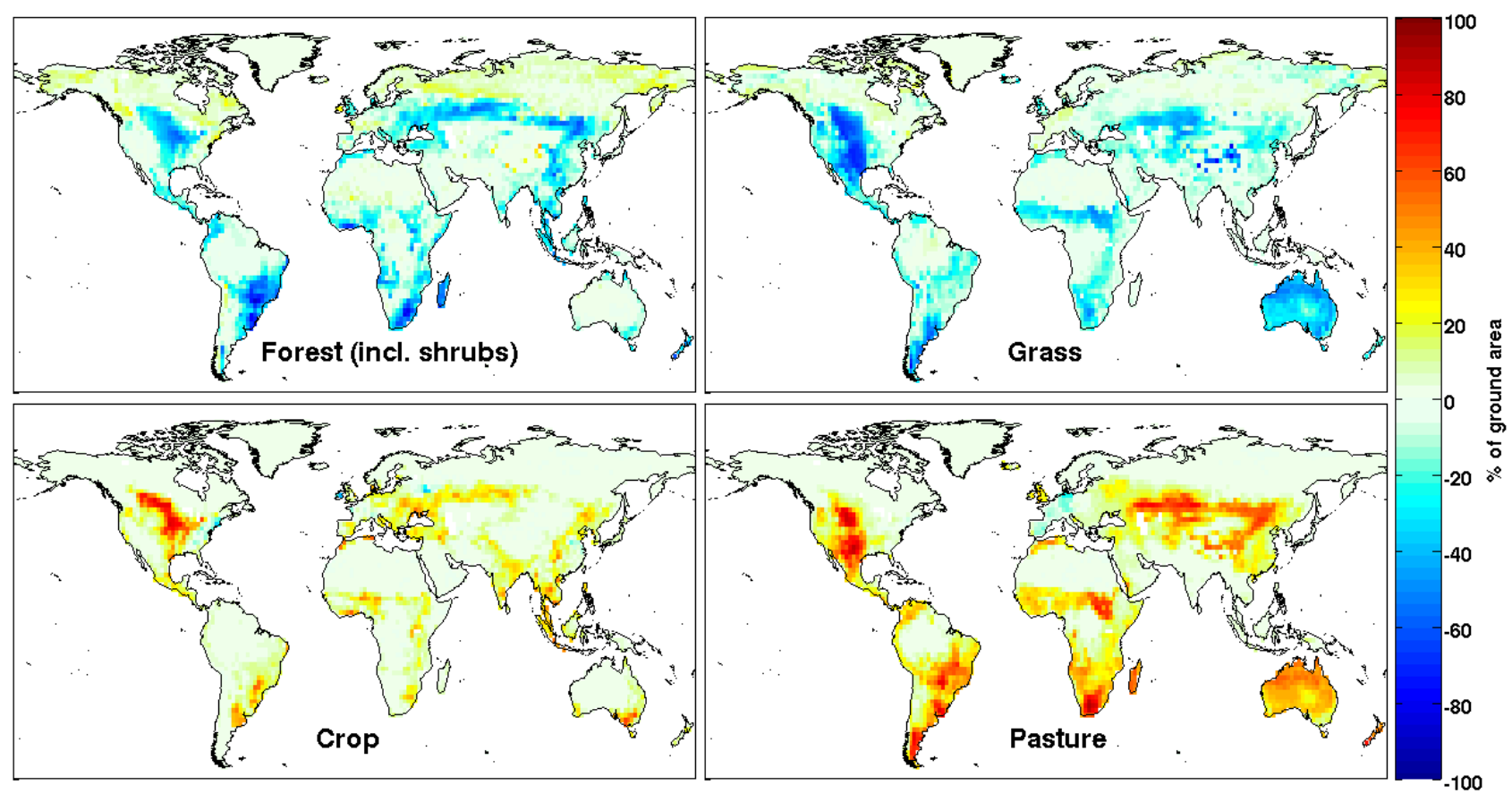

Figure 2. Modelled change in area of different vegetation types during the historical period (1850-2005).

1.4 $\mathrm{Pg} \mathrm{C} \mathrm{yr}^{-1}$ in the early 1980 s with a peak in the $1950 \mathrm{~s}$. After 1990 it drops to about $1.2 \mathrm{Pg} \mathrm{Cyr}^{-1}$ at the end of the historical period. Negative LCE is found in regions where large areas of grassland have been converted to pasture (compare Fig. 4, upper left panel with Fig. 2 and Supplement Fig. S6), because conversion from natural to agricultural land decreases the carbon emissions from wildfires (which in JSBACH/CBALANCE are suppressed on pastures and croplands). In contrast to forests, grassland has low density of above-ground carbon and a short turnover period of the carbon. Therefore the reduction in wildfire activity can cause reductions in the carbon emission larger than the emissions from LULCC in such regions. This effect is not obvious in regions converted to crop, probably since - due to the pasture rule - a higher fraction of this area was originally forest. The regional patterns of LCE (Fig. 4, left panels) do not change much between hist and RCP2.6/RCP8.5 with the exception of Africa south of the Sahara, where the LCEs increase substantially. RCP4.5 on the contrary shows large-scale negative LCE due to the re-establishment of natural areas, the only exceptions being East Asia and eastern Africa, where agricultural expansion continues. Globally, RCP2.6 and RCP8.5 both show increasing LCE in the beginning of the 21st century (Fig. 3), peaking around 2030 (2070) at about 2.2 (2.5) $\mathrm{Pg} \mathrm{Cyr}^{-1}$ for RCP2.6 (RCP8.5) followed by a decrease thereafter, steepest in RCP2.6, so that the LCE in 2100 is about 0.3 (1.5) $\mathrm{Pg} \mathrm{C} \mathrm{yr}^{-1}$. The global LCE in RCP4.5 drops steeply at the beginning of the 21 st century and continues to 


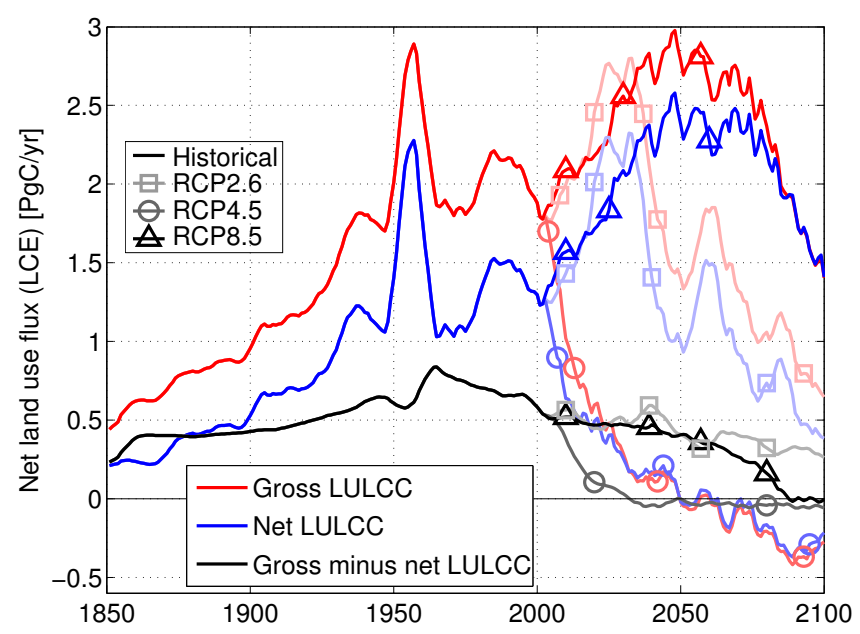

Figure 3. Seven-year running mean of land-use carbon emissions from gross and net transitions as well as the difference between them.

decrease, reaching about $-0.2 \mathrm{PgC} \mathrm{yr}^{-1}$ in 2100 . The LCE caused by wood harvest can be assessed by replacing the reference runs (without LULCC runs) with runs using transient wood harvest. This reduces the LCE by about $0.09,0.22,0.26$ and 0.32 PgC/yr for historical, RCP2.6, RCP4.5 and RCP8.5, respectively (see Supplement Fig. S7 and Table 2).

\subsubsection{LCE differences between net and gross LULCC}

Applying gross LULCC converts larger areas than net LULCC and thus generally leads to larger LCE (Figs. 4, right panels and 3). In 1850 the difference is about $0.3 \mathrm{Pg} \mathrm{C} \mathrm{yr}^{-1}$ (more than $100 \%$ of the net LCE) and it increases to about $0.6 \mathrm{PgC} \mathrm{yr}^{-1}$ in 1960 , where it jumps to $0.9 \mathrm{Pg} \mathrm{Cyr}^{-1}$ and decreases during the rest of the experiment period. In 2005 the difference is about $0.5 \mathrm{PgC} \mathrm{yr}^{-1}$. The total LCE (Table 2, bottom) during the historical period is about $85 \mathrm{PgC}$ - almost $60 \%$ - larger when applying gross instead of net LULCC. Reversely formulated, net LULCC results in a lowering of LCE of $38 \%$ compared to gross LULCC. The LCE difference between net and gross LULCC is decreasing during all the RCPs. RCP4.5 has a sudden drop in the beginning of the 21 st century, reaching essentially $0 \mathrm{PgC} \mathrm{yr}^{-1}$ in 2030, thereafter staying constant. In RCP2.6 and RCP8.5 the decrease is more steady throughout the century, though the descent becomes steeper in RCP8.5 after 2060, reaching $0 \mathrm{PgC}_{\mathrm{yr}}{ }^{-1}$ around year 2090. In RCP2.6 the difference is about $0.3 \mathrm{Pg} \mathrm{Cyr}^{-1}$ in 2100. By using gross LULCC, a total of $40 \mathrm{PgC}(34 \%), 2.4 \mathrm{PgC}(32 \%)$ and $30 \mathrm{Pg} \mathrm{C}(15 \%)$ (Table 2, bottom) is added to the LCE during RCP2.6, RCP4.5 and RCP8.5, respectively.

In many regions the difference between LCE from gross and net LULCC (Fig. 4, right panels) is of the same magnitude as the LCE from the net LULCC (left panels) - in parts of southern Africa even exceeding these. The patterns of ad- ditional LCE from the gross LULCC do not change much from the historical period to RCP2.6/RCP8.5 with the exception of a shift from the coastal southern Africa to the more central parts. Most of the patterns are also found in RCP4.5 with a major difference in southwestern Africa, where the gross LULCC leads to an even larger negative LCE than the net LULCC.

The discussed differences between LCE from gross and net LULCC contain a compensating contribution from the changing wildfire regimes. The average carbon emission from wildfires in hist_gross are reduced by about $0.04 \mathrm{Pg} \mathrm{C} \mathrm{yr}^{-1}(1.6 \%)$ to a total of $2.71 \mathrm{Pg} \mathrm{C} \mathrm{yr}^{-1}$ compared to hist_net. The reduction is 5.5, 3.5 and 5.3\% in RCP2.6, RCP4.5 and RCP8.5, respectively.

\section{Discussion and summary}

Using the land carbon model of MPI-ESM, CBALANCE, this study demonstrates that ignoring subgrid-scale LULCC conversions like shifting cultivation (net LULCC), as done by many of the models participating in CMIP5, leads to much lower LCE than when such conversions are included (gross LULCC). In the four studied scenarios (historical, RCP2.6, RCP4.5 and RCP8.5), the cumulated LCE estimates are lowered by $85,40,2.4$ and $30 \mathrm{PgC}$ (Table 2), corresponding to ignoring emissions of $0.54,0.32,0.02$ and $0.42 \mathrm{Pg} \mathrm{C} \mathrm{yr}^{-1}$, respectively on average (equivalent to up to $7 \%$ of 2005 fossil fuel emissions as reported by Boden et al. (2013); In 2005 the total gross LCE were equivalent to $18 \%$ of fossil fuel emissions). The differences between the LULCC methods are getting smaller towards year 2100 and vanish entirely at the end of RCP4.5 and RCP8.5. This convergence of the methods arises because some regions (mainly in the transition zones at the edges of the tropical forests) get larger LCE using net than gross transitions while other regions keep the usual sign of the difference. That net LCE can get larger than gross LCE is possible where the two methods have resulted in either different regrowth potentials or slightly different vegetation distribution (e.g. less desert when using net transitions) and these differences are interacting with a more productive (higher $\mathrm{CO}_{2}$ ) climate. In some regions both explanations play a role. A similar convergence of net and gross LCE is not found by Stocker et al. (2014). This emphasizes that secondorder effects of changing between the two transition types may significantly change the results. These second-order effects are to a high degree dependent on implementation and thus model specific. Assuming that the implementation of the two LULCC methods in MPI-ESM would lead to exactly the same vegetation distribution and state, the LCE difference between the methods would increase - especially in the future scenarios.

Representing LULCC via gross transitions extends the LULCC representation by also resolving shifting cultivation and other subgrid-scale LULCC processes in addition to the 


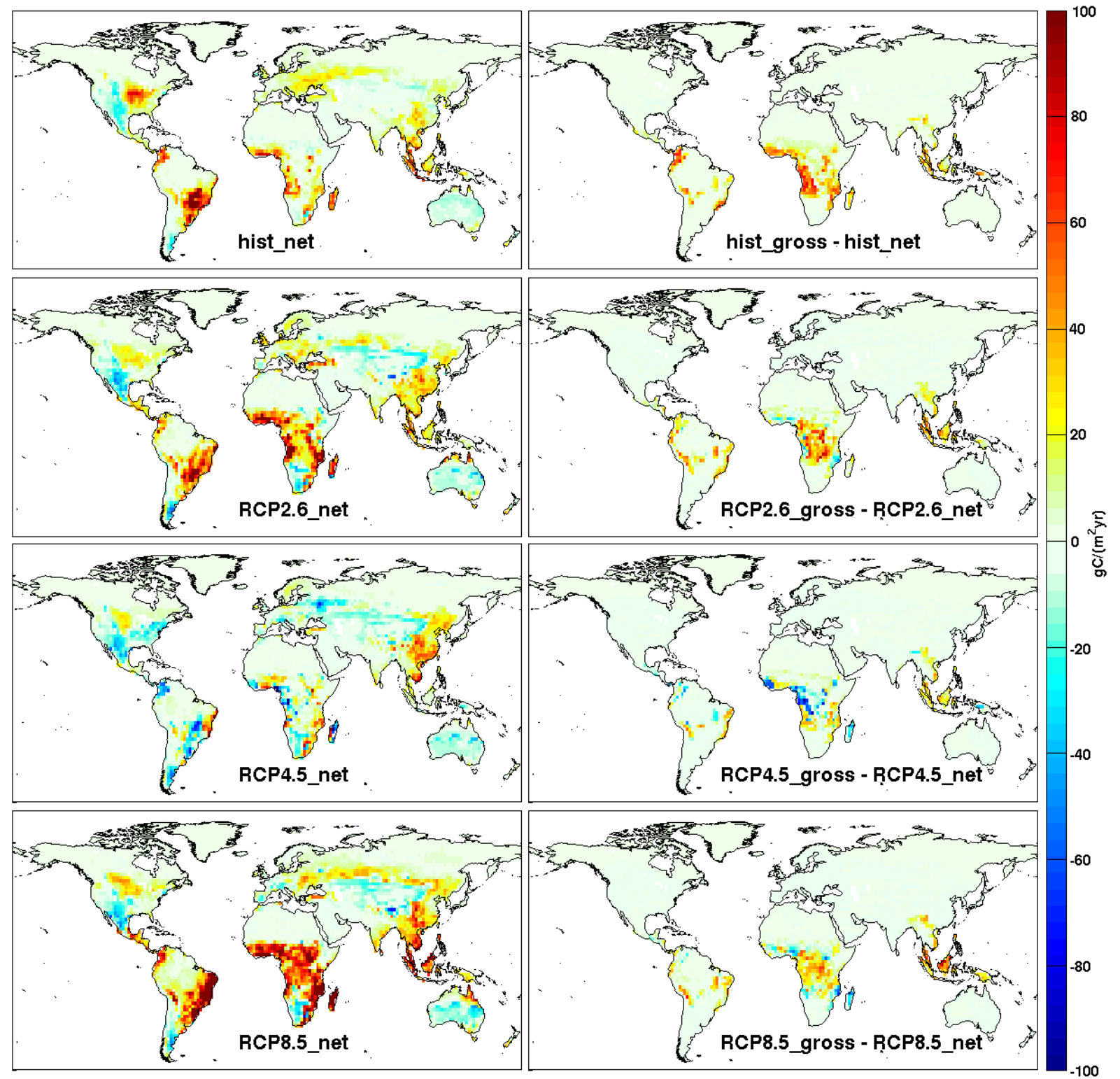

Figure 4. Geographical distribution of annual average land-use carbon emission using net transitions (left column) and the difference between gross and net transitions (right column).

net transitions. Since gross transitions include a more complete description of the LULCC, this should be the preferred method for modelling LULCC; however, presently only few models are capable of doing so.

Gross transitions need more input data. Accurate historical information on LULCC is scarce and thus Hurtt et al. (2011) applied a rather coarse and static map of the location of shifting cultivation (mostly in the tropics) and assumed a fixed period for which agricultural land is cultivated before it is again abandoned (15 years, corresponding to an abandonment rate of $6.7 \%$ ). In reality the extent and cycle period of shifting cultivation is strongly dependent on location and time (Lanly, 1985; Bruun et al., 2006; Lojka et al., 2011;
Ranjan and Upadhyay, 1999; Ramankutty et al., 2007). Hurtt et al. (2011) assesses the uncertainty of the LULCC data by testing a large ensemble of different assumptions, resulting in a large range of converted areas (both net and gross). Of this ensemble, the "Land-Use Harmonization Dataset" is the member considered to be most likely. Ideally the uncertainty in LCE for both gross and net transitions as well as the difference between them would be assessed by feeding the ESMs with more of the ensemble members. Despite the uncertainties associated with existing data sets of LULCC and their assumptions on subgrid-scale conversions, it is known that shifting cultivation plays a role in global agriculture and 
therefore the estimates of LCE from the net transitions are highly likely to be underestimated.

Among the estimates of LCE reported in the studies by Houghton et al. (2012) and Brovkin et al. (2013), the estimates presented here are towards the high end when the MPIESM standard (gross) LULCC is applied. Houghton et al. (2012) reported a multi-method average estimate of LCE of 1.14 $\mathrm{Pg} \mathrm{C} \mathrm{yr}^{-1}$ for the $1990 \mathrm{~s}$, including the JSBACH results of Pongratz et al. (2009), who applied the net LULCC data of Pongratz et al. (2008). Applying net LULCC in CBALANCE reduces the $\mathrm{LCE}$ from $2.05 \mathrm{Pg} \mathrm{C} \mathrm{yr}^{-1}$ to $1.40 \mathrm{Pg} \mathrm{C} \mathrm{yr}^{-1}$ during the 1990s, thus removing most of the difference to Houghton et al. (2012)'s "method-mean".

However, the results presented here question the value of such "method-means", where some ensemble members are applying net transitions, others gross. Only ESMs implementing gross methods can be expected to reproduce the results of bookkeeping models like the one presented in Houghton et al. (1983). Ensemble means and spreads of "method-ensembles" such as the CMIP5 project or the ensemble presented in Houghton et al. (2012) may be misleading, since they contain members which are not truly comparable. Building sub-ensembles containing only comparable members may ease the interpretation and narrow the range of LCE estimates. Brovkin et al. (2013) compares for a slightly different experimental setup than ours the (cumulated) LCE for a sub-set of five CMIP5 models. Indeed, the two models with highest LCE (MPI-ESM and MIROC) use gross transitions, while the others use net transitions. MPI-ESM is the only one of the five models implementing wood harvest.

Wood harvest is implemented very differently in the CMIP5 models which either ignore it completely, include it as a removal of carbon or as transitions from primary and/or secondary to secondary land (Appendix A in Brovkin et al., 2013; Shevliakova et al., 2013). In a steady state, the carbon emissions from wood harvest would be compensated by regrowth of forests (see the discussion in Ramankutty et al., 2007) and would thus not add to anthropogenic carbon emissions. However, according to the "Land-Use Harmonization Dataset" wood harvest is (almost) monotonically increasing from 0.2 $\mathrm{Pg} \mathrm{Cyr}^{-1}$ in 1850 to $1.8-3.5 \mathrm{PgC} \mathrm{yr}^{-1}$ in 2100 (dependent on the RCP scenario). The total prescribed harvest in "historical", RCP2.6, RCP4.5 and RCP8.5 is 94, 153, 168 and $232 \mathrm{PgC}$, respectively, but in this study, wood harvest has been quantified to contribute only 13, 21, 25 and $31 \mathrm{PgC}$ to the LCE, respectively. Thus, though no steady state is obtained, regrowth still largely compensates the wood harvest. Except for RCP4.5, at most $13 \%$ of the total gross LCE stems from wood harvest which is thus only a minor contributor to the total LCE. On the other hand, the LCE from wood harvest is the dominating part of the LCE in RCP4.5 and without this contribution LCE would be negative for this scenario. Since wood harvest is equally a part of the net and gross LCE, the absolute difference between the methods is not affected by the treatment of wood harvest. Our estimates of LCE from wood harvest are 57-81\% of the respective numbers presented by Stocker et al. (2014). This difference puts a focus on the net LCE from wood harvest as being highly sensitive to assumptions on the fate of the harvested carbon and thus turnover times of the non-living carbon pools. These are badly constrained for global models.

The converted areas are dependent on the exact model implementation. Thus our converted areas are much smaller (our gross (net) converted areas are $\approx 50 \%$ (70\%) of theirs) than those presented in Hurtt et al. (2011), who included secondary natural vegetation. Compared to Shevliakova et al. (2013) (their Fig. 1b) our gross conversions are higher than their "gross from fractions", while our net conversions are slightly lower than theirs. They include secondary vegetation with age classes and area of harvested wood. Lawrence et al. (2012) get - using a net method - a total of converted areas somewhat higher than ours - most likely to be due to different treatment of desert areas.

The difference between converted areas calculated by using gross and net transitions arises due to two different effects, the most important being the subgrid-scale cancellation of transitions represented in the data set of Hurtt et al. (2011). When applying net transitions, the remapping from the original data to the model grid introduces an additional cancellation from opposing land conversions in adjacent grid cells. For a typical state-of-the-art ESM with a resolution of $2^{\circ}$ the resolution reduction of converted area has been estimated (see Appendix A) to be 1-5\% for the different scenarios. Since the reduction of converted area mainly occurs in areas of intensive LULCC and thus below-average carbon stocks, the effect of resolution on the LCE is expected to be less than the effect on the converted area. The differences between converted area of net and gross LULCC disappear entirely only when the model resolution resolves the individual plots of shifting cultivation. Since the area of a plot typically is $\mathrm{O}$ (1 ha) (Bruun et al., 2006; Lojka et al., 2011), this would require a reduction of grid cell area by a factor of $\mathrm{O}\left(10^{6}\right)$ compared to current generation of ESMs and an almost similar increase in the need for accurate input data. It is not realistic to expect any of these requirements to be fulfilled in the foreseeable future.

In reality both biogeophysical and biogeochemical parameters are affected differently by net and gross transitions, e.g. through different maturity of the forests leading to both different albedo, roughness length and carbon uptake. In JSBACH/CBALANCE the state of the plants is only reflected in the carbon stocks and can thus neither change the NPP nor the biogeophysical parameters. Therefore changes in these parameters can only occur though changes in the vegetation distribution. Since the experiments with gross and net LULCC are (net: almost) identical to the coupled CMIP5 runs with MPI-ESM, which delivered the forcing data for this study, both these experiments are consistent with respect to the biogeophysical feedbacks with the atmosphere. Applying the same atmospheric forcing to the reference runs (the runs 
without LULCC) disregards the effects of vegetation distribution which differs between these experiments, on the atmosphere. Since the calculation of net and gross LCE uses the same reference run and the absolute LCE differences between the two methods are entirely independent of the reference run, disregarding these feedbacks does not change the main conclusions of this study. The MPI-ESM experiments delivering the forcing data for our experiments are performed with prescribed transient atmospheric $\mathrm{CO}_{2}$ concentration and thus the most important biogeochemical feedback is treated consistently with the coupled runs despite the use of an offline carbon model.
This study demonstrates that implementation details of LULCC may significantly alter the estimates of LCE and thus the estimates of the effects of LULCC on climate and climate changes. Most studies up to now deal with implementations of net LULCC and are likely to underestimate the LCE. 
Appendix A: Estimating resolution dependency of net LULCC

Based on the original $0.5^{\circ}$ resolution data of Hurtt et al. (2011) the resolution effect on the net converted area has been estimated by joining a number of grid cells together to produce a data set with a specified resolution; thereafter the conversions are reduced to net conversions as described in Sect. 2.2. The data have not been masked by any land-sea masks. The conversions taken into account are those regarded by JSBACH/CBALANCE: conversions from primary to secondary land are ignored and in all other conversions primary and secondary land is treated as being the same class. Figure A1 shows the relative reduction in net converted area relative to the original data after joining a number of adjacent cells (e.g. $2^{\circ}$ resolution joins $4 \times 4$ cells) to reduce resolution. Not surprising, the general trend is that the coarser the resolution, the higher the ignored fraction of the conversions will be. However, the slope of reduction is largest for very high resolutions and the different scenarios show very different resolution dependencies. The latter is related to the heterogeneity of the provided LULCC data which again is related to the resolution of the source data/Integrated Assessment Model (IAM) from which the LULCC data stem (historical: Hurtt et al. (2011), RCP2.6: van Vuuren et al. (2011b), RCP4.5: Thomson et al. (2011), RCP8.5: Riahi et al., 2011) - the coarser the source data/model, the smoother the data and the smaller the reduction. For state-of-the-art ESMs with resolutions of $1-3^{\circ}$ the reduction of converted area with resolution is however a second-order effect compared to ignoring the subgrid-scale conversions, which already at $0.5^{\circ}$ resolution amounts to $\approx 2 / 3$ for the historical period and $\approx 90 \%$ in any of the RCPs of the total conversions (Supplement Figs. S4 and S5).

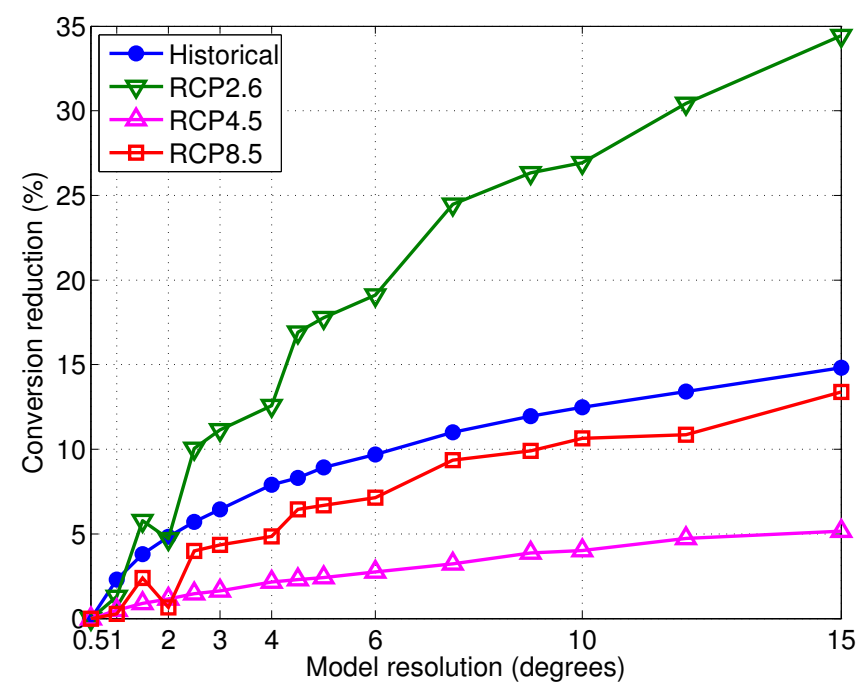

Figure A1. Relative reduction of area converted by net LULCC as function of resolution, using $0.5^{\circ}$ as reference. Only resolutions with an integer number of cells around the globe have been calculated. 


\section{The Supplement related to this article is available online at doi:10.5194/bg-11-4817-2014-supplement.}

The service charges for this open access publication have been covered by the Max Planck Society.

Edited by: P. Stoy

\section{References}

Boden, T. A., Marland, G. and Andres, R. J.: Global, Regional, and National Fossil-Fuel $\mathrm{CO}_{2}$ Emissions, doi:10.3334/CDIAC/00001_V2013, 2013.

Brovkin, V., Raddatz, T., Reick, C. H., Claussen, M., and Gayler, V.: Global biogeophysical interactions between forest and climate, Geophys. Res. Lett., 36, L07405, doi:10.1029/2009GL037543, 2009.

Brovkin, V., Boysen, L., Arora, V. K., Boisier, J. P., Cadule, P., Chini, L., Claussen, M., Friedlingstein, P., Gayler, V., van den Hurk, B. J. J. M., Hurtt, G. C., Jones, C. D., Kato, E., de NobletDucoudre, N., Pacifico, F., Pongratz, J., and Weiss, M.: Effect of anthropogenic land-use and land-cover changes on climate and land carbon storage in CMIP5 projections for the twenty-first century, J. Climate, 26, 6859-6881, 2013.

Bruun, T., Mertz, O., and Elberling, B.: Linking yields of upland rice in shifting cultivation to fallow length and soil properties, Agr. Ecosyst. Eviron., 113, 139-149, 2006.

Denman, K. L., Brasseur, G., Chidthaisong, A., Ciais, P., Cox, P. M., Dickinson, R. E., Hauglustaine, D., Heinze, C., Holland, E., Jacob, D., Lohmann, U., Ramachandran, S., da Silva Dias, P. L., Wofsy, S. C., and Zhang, X.: Couplings between changes in the climate system and biogeochemistry, in: The Physical Science Basis: Contribution of Working Group I to the Fourth Assessment Report of the Intergovernmental Panel on Climate Change, edited by: Solomon, S., Qin, D., Manning, M., Chen, Z., Marquis, M., Averyt, K. B., and Tignor, M., Cambridge University Press, Cambridge, 499-587, 2007.

Giorgetta, M. A., Jungclaus, J., Reick, C. H., Legutke, S., Bader, J., Böttinger, M., Brovkin, V., Crueger, T., Esch, M., Fieg, K., Glushak, K., Gayler, V., Haak, H., Hollweg, H.-D., Ilyina, T., Kinne, S., Kornblueh, L., Matei, D., Mauritsen, T., Mikolajewicz, U., Mueller, W., Notz, D., Pithan, F., Raddatz, T., Rast, S., Redler, R., Roeckner, E., Schmidt, H., Schnur, R., Segschneider, J., Six, K. D., Stockhause, M., Timmreck, C., Wegner, J., Widmann, H., Wieners, K.-H., Claussen, M., Jochem, M., and Stevens, B.: Climate and carbon cycle changes from 1850 to 2100 in MPI-ESM simulations for the coupled model intercomparison project phase 5, J. Adv. Model. Earth Syst., 5, 572-597, 2013.

Houghton, R. A., Hobbie, J. E., Melillo, J. M., Moore, B., Peterson, B. J., Shaver, G. R., and Woodwell, G. M.: Changes in the carbon content of terrestrial biota and soils between 1860 and 1980: a net release of $\mathrm{CO}_{2}$ to the atmosphere, Ecol. Monogr., 53, 235-262, 1983.

Houghton, R. A., House, J. I., Pongratz, J., van der Werf, G. R., DeFries, R. S., Hansen, M. C., Le Quéré, C., and Ramankutty, N.: Carbon emissions from land-use and land-cover change, Biogeosciences, 9, 5125-5142, doi:10.5194/bg-9-5125-2012, 2012.
Hurtt, G. C., Frolking, S., Fearon, M. G., Moore, B., Shevliakova, E., Malyshev, S., Pacala, S. W., and Houghton, R. A.: The underpinnings of land-use history: three centuries of global gridded land-use transitions, wood-harvest activity, and resulting secondary lands, Glob. Change Biol., 12, 1208-1229, 2006.

Hurtt, G. C., Chini, L. P., Frolking, S., Betts, R. A., Feddema, J., Fischer, G., Fisk, J. P., Hibbard, K., Houghton, R. A., Janetos, A., Jones, C. D., Kindermann, G., Kinoshita, T., Goldewijk, K. K., Riahi, K., Shevliakova, E., Smith, S., Stehfest, E., Thomson, A., Thornton, P., van Vuuren, D. P., and Wang, Y. P.: Harmonization of land-use scenarios for the period 1500-2100: 600 years of global gridded annual land-use transitions, wood harvest, and resulting secondary lands, Clim. Change, 109, 117-161, 2011.

Jain, A. K., Meiyappan, P., Song, Y., and House, J. I.: $\mathrm{CO}_{2}$ emissions from land-use change affected more by nitrogen cycle, than by the choice of land-cover data, Glob. Change Biol., 19, 2893 2906, 2013.

Lanly, J. P.: Defining and measuring shifting cultivation, Unasylva, 37, 17-21, 1985.

Lawrence, P. J., Feddema, J. J., Bonan, G. B., Meehl, G. A., O'Neill, B. C., Oleson, K. W., Levis, S., Lawrence, D. M., Kluzek, E., Lindsay, K., and Thornton, P. E.: Simulating the biogeochemical and biogeophysical impacts of transient land cover change and wood harvest in the Community Climate System Model (CCSM4) from 1850 to 2100, J. Climate, 25, 3071-3095, 2012.

Lojka, B., Banout, J., Banoutova, L., Verner, V., and Van Damme, P.: Diversity of shifting cultivation cycles among small-scale farmers in Peruvian Amazon, Agr. Sci., 2, 68-77, 2011.

Pongratz, J., Reick, C., Raddatz, T., and Claussen, M.: A reconstruction of global agricultural areas and land-cover for the last millennium, Global Biogeochem. Cy., 22, GB3018, doi:10.1029/2007GB003153, 2008.

Pongratz, J., Reick, C. H., Raddatz, T., and Claussen, M.: Effects of anthropogenic land-cover change on the carbon cycle of the last millennium, Global Biogeochem. Cy., 23, GB4001, doi:10.1029/2009GB003488, 2009.

Pongratz, J., Reick, C. H., Houghton, R. A., and House, J. I.: Terminology as a key uncertainty in net land-use and land-cover change carbon flux estimates, Earth Syst. Dynam., 5, 177-195, 2014.

Raddatz, T. J., Reick, C. H., Knorr, W., Kattge, J., Roeckner, E., Schnur, R., Schnitzler, K.-G., Wetzel, P., and Jungclaus, J.: Will the tropical land biosphere dominate the climate-carbon cycle feedback during the twenty-first century?, Clim. Dynam., 29, 565-574, 2007.

Ramankutty, N., Gibbs, H. K., Achard, F., Defriess, R., Foley, J. A., and Houghton, R. A.: Challenges to estimating carbon emissions from tropical deforestation, Glob. Change Biol., 13, 51-66, 2007.

Ranjan, R. and Upadhyay, V.: Ecological problems due to shifting cultivation, Curr. Sci. India, 77, 1246-1250, 1999.

Reick, C. H., Raddatz, T., Pongratz, J., and Claussen, M.: Contribution of anthropogenic land-cover change emissions to preindustrial atmospheric $\mathrm{CO}_{2}$, Tellus B, 62, 329-336, 2010.

Reick, C. H., Raddatz, T., Brovkin, V., and Gayler, V.: Representation of natural and anthropogenic land-cover change in MPIESM, J. Adv. Model. Earth Syst., 5, 459-482, 2013. 
Riahi, K., Rao, S., Krey, V., Cho, C., Chirkov, V., Fischer, G., Kindermann, G., Nakicenovic, N., and Rafaj, P.: RCP 8.5-A scenario of comparatively high greenhouse gas emissions, Clim. Change, 109, 33-57, 2011.

Schneck, R., Reick, C. H. and Raddatz, T.: Land contribution to natural $\mathrm{CO}_{2}$ variability on time scales of centuries, J. Adv. Model. Earth Syst., 5, 354-365, 2013.

Shevliakova, E., Pacala, S. W., Malyshev, S., Hurtt, G. C., Milly, P. C. D., Caspersen, J. P., Sentman, L. T., Fisk, J. P., Wirth, C., and Crevoisier, C.: Carbon cycling under 300 years of land-use change: importance of the secondary vegetation sink, Global Biogeochem. Cy., 23, GB2022, doi:10.1029/2007GB003176, 2009.

Shevliakova, E., Stouffer, R. J., Malyshev, S., Krasting, J. P., Hurtt, G. C., and Pacala, S. W.: Historical warming reduced due to enhanced land carbon uptake, P. Natl. Acad. Sci. USA, 110, 16730-16735, 2013.

Stocker, B., Feissli, F., Strassmann, K., Spahni, R., and Joos, F.: Past and future carbon fluxes from land-use change, shifting cultivation and wood harvest, Tellus B, 66, 23188, doi:10.3402/tellusb.v66.23188, 2014.
Taylor, K. E., Stouffer, R. J., and Meehl, G. A.: An overview of CMIP5 and the experiment design, B. Am. Meteorol. Soc., 93, 485-498, 2012.

Thomson, A. M., Calvin, K. V., Smith, S. J., Kyle, G. P., Volke, A., Patel, P., Delgado-Arias, S., Bond-Lamberty, B., Wise, M. A., Clarke, L. E., and Edmonds, J. A.: RCP4.5: a pathway for stabilization of radiative forcing by 2100 , Climatic Change, 109 , 77-94, 2011.

van Vuuren, D. P., Edmonds, J., Kainuma, M., Riahi, K., Thomson, A., Hibbard, K., Hurtt, G. C., Kram, T., Krey, V., Lamarque, J.-F., Masui, T., Meinshausen, M., Nakicenovic, N., Smith, S. J., and Rose, S. K.: The representative concentration pathways: an overview, Climatic Change, 109, 5-31, 2011a.

van Vuuren, D. P., Stehfest, E., den Elzen, M. G. J., Kram, T., van Vliet, J., Deetman, S., Isaac, M., Goldewijk, K. K., Hof, A., Beltran, A. M., Oostenrijk, R., and van Ruijven, B.: RCP2.6: exploring the possibility to keep global mean temperature increase below 2 degrees C, Climatic Change, 109, 95-116, 2011 b.

Williams, M.: Deforesting the Earth: from Prehistroy to Global Crisis, University of Chicago Press, 2006. 